\title{
Lemmikloomad Eesti veebis viimasel viiel aastal ${ }^{1}$
}

\begin{abstract}
Liisa Vesik
Teesid: Artiklis iseloomustatakse muutusi lemmikloomi käsitlevatel Eesti avalikel veebilehtedel ja foorumites perioodil 2004-2008. Veebilehtede areng on kaasa toonud muutused foorumite tehnilise külje ning suured muutused sisu osas, peegeldades nihkeid ühiskonna väärtushinnangutes. Veebilehel on oluline esindusfuktsioon, kusjuures veebilehe asumine ee-lõpulisel aadressil lisab sellele autoriteetsust. Märkimisväärne on foorumite liikumine anonüümselt kasutajaskonnalt registreerunud ja identifitseeritava suunas ning netiketi järgimise kontrolli tõhustumine. Kuulutusi avaldatakse veebis rohkem, sealhulgas ka tasulisi kuulutusi. Lisaks teabe levitamisele on tekkinud ka foorumid ja portaalid, millel on peamiselt meelelahutuslik eesmärk. Kasutajad valivad veebikeskkondi mitte ainult disaini ega kasutusmugavuse alusel, vaid kombinatsioonina sellest ning lähtuvalt vajadusest, mida leht rahuldab.
\end{abstract}

Märksõnad: anonüümsus, lemmikloom, loomaportaal, veebikogukond

Artiklis iseloomustatakse muutusi lemmikloomi käsitlevatel Eesti avalikel veebilehtedel ja foorumites perioodil 2004-2008. Loomaveebid koondavad kasutajaid nii loomakeskselt (näiteks Delfi Lemmiklooma foorum) kui ka loomadega tegeleva organisatsiooni keskselt (näiteks Eesti Loomakaitse Seltsi foorum). Võrgustike liikmeid ühendab loomade omamise kõrval tahe tutvustada neid foorumites ja veebi vahendusel, liidavad ühised loomadega seotud huvid ja tegevused. Teatavate kokkulangevate väärtushinnangute kõrval on loomaomanikud erineva maailmavaatega isikud, kelle veebikäitumine ja loodav veebisisu peegeldab muutusi kogukonnas, väärtushinnangutes ja inimeste suhtumises loomadesse. Foorumite liikmed käituvad sama mustri järgi kui muud veebikogukondade liikmed - prevaleerivad igapäevase käitumise ja hoolduse küsimused ning aktiivseid osalejaid on palju vähem kui passiivseid lugejaid, kes ei kommenteeri ega sekku omalt poolt kunagi (Fialkova \& Jelenevskaja 2001, Vesik 2004). Siiski ei ole artiklis vaatluse all inimeste ja loomade suhted, loomade võimalused ja õigused käituda nagu nemad tahavad ega inimeste valmi- 
dus seda lubada (vt ka Beck \& Katcher 1996), vaid muutused lemmikloomadega seotud Eesti veebis.

Lähema vaatluse all on nelja viimase aasta jooksul toimunud muutused, reklaami muutumine, inimeste identifitseeritavus ja anonüümsuse kadu foorumites, täiskasvanulik käitumine vs nunnutamine, abiorganisatsioonide tekkimine ning foorumite nõuded kasutajate käitumisele.

\section{Lühiülevaade loomaveebist aastal 2004}

2004. aasta oktoobrikuus toimunud teisel interdistsiplinaarsel konverentsil "Inimesed ja lemmikloomad" andsin lühiülevaate eestikeelsetest lemmikloomadega seotud portaalidest ja foorumitest (Vesik 2004). Tookord leidus mitmekülgset informatsiooni lemmikloomade kohta nii suuremates portaalides nagu Delfi kui ka ainult loomadele pühendatud portaalides (nt Lontu, Lemmik), milles võtsid sõnad loomaomanikud, lemmikloomakasvatajad, loomatoitude ja -tarvetega tegelejad ja aktiivsed loomahuvilised. Suurtes kuulutuselehtedes nagu Kuldne Börs olid lemmikloomad esindatud eraldi kategooriana. Oma veebiväravad olid ka Eesti Loomakaitse Seltsil ja kodutute loomade varjupaikadel.

Portaalid vahendasid mitmekesist infot näiteks tõugude iseloomuomaduste kohta, sisaldasid artikleid loomade käitumisest, arsti nõuandeid ning vastuseid esitatud küsimustele, loomade müügi- ja otsimisteateid, praktilisi näpunäiteid, uudiskirjanduse reklaami jpm. Sisuliselt igast portaalist võis leida ka loomakliinikute aadressid. Foorumitel olid oma moderaatorid ja võrgustik, kes suhtles aktiivselt veebis, kuid kohtus ka lemmikloomaüritustel (võistlused, näitused, kokkutulekud).

Oma veebikodud olid populaarsematel lemmikloomadel: (tõu)koerad, kassid, hobused, akvaariumis elavad kalad ja kilpkonnad, samuti närilised.

Tekkisid ka ühe pere lemmikute "isiklikud" kodulehed, mida haldasid nende peremehed. Tihti oli selline lehekülg üks pereliikmete isiklikest lehekülgedest. Seal leidus nii andmeid looma kohta, fotosid, kui ka jutukesi lemmiku käekäigust.

Kummalisel kombel ei olnud ühtegi aktiivset loomade postiloendit.

Aktiivne ja mitmekülgne veebitegevus ning kahes telekanalis edastatav lemmikloomade saade osutas, et loomadel on linnainimeste elus üsna oluline koht. 


\section{Mõned aastad hiljem}

Ethel Kiilmaa hindas olukorda aastal 2001:

Statistika järgi on Eesti elanikel võrreldes näiteks põhjanaabritega alati palju lemmikloomi olnud. Ent kui Skandinaavia maades peab kodus loomi vähem inimesi, aga rohkem isendeid korraga, siis meil on olukord vastupidine. Enamasti on peres üks, äärmisel juhul kaks lemmikut (Kiilmaa 2001).

Sestsaadik on olukord kardinaalselt muutunud - aina rohkemates peredes on loomi mitu ning veebis lausa julgustatakse loomale teist samast liigist kaaslaseks võtma.

Veebipõhise sotsiaalse vastastikuse mõju põhjustena on esile tõstetud mitmeid motivaatoreid. Lemmikloomadega seoses on olulised näiteks lõimed.

Kasutajad valivad lugemiseks teemalõngasid vastavalt oma erihuvidele, uudishimule või teemasse postitavate kasutajate mõjule. Seega koondavad teemalõngad sarnaste huvidega kasutajaid ning tekib võimalus stimuleerivamaks suhtluseks (Chayko 2002: 96).

Mary Chayko arvates on virtuaalse kogukonna moodustamisel oluline roll sarnasel mentaalsusel ehk teisisõnu on isikud sotsiomentaalsete sidemete kaudu ühendatud. Tema arvates on üks selliste kodulehtede suhtlemise omapärasid võimalus anda edasi teadmisi.

Meeletu huvipakkuvate teemaniššide hulga juures on mingi alaga hästi kursis olevate kasutajatega diskussiooni astumisel või nende postituste lugemisel hämmastav kasutegur (Chayko 2002: 96).

Osalt nende põhjustega on seotud ka Eesti veebis mõne aastaga toimunud suured muutused. Nii selle osas, kes on lemmikute veebis suuremad tegijad, kui ka selle osas, millised lehed on üldse olemas.

Kui võrrelda 2008. aasta seisu 2004. aastaga, on mänguplatsilt kadunud suur pisinäriliste portaal Lontu, suurest koera- ja üldse loomafoorumist on tõukeskseks taandunud Bokseripesa ning tagaplaanile jäänud nii Verekoer kui ka Lemmik. Nende asemel on esile kerkinud näriliste ja lindude portaal Pisi ja jõuliselt esiplaanile nihkunud Koertekoda, hiljutised uustulnukad on Kiisu.ee ja Kutsu.ee. Olulisel määral on oma veebilehti arendanud akvaristikahuvilised ja roomajate kasvatajad.

Sellest saadik, kui kadus anonüümsus ja kasutaja pidi end registreerima ning sisse logima, on näiteks Koer.ee ja Lemmik.ee foorumid jäänud väiksemaks. Küll aga vahendab Lemmik.ee protaaliuudiseid ehk siis koondab ajakir- 
jandusest linke loomade teemal ning Koer.ee on endiselt tuntud oma tõututvustuste ja artiklite poolest.

Veebilehe olemasolu ja sisukus on muutunud oluliseks visiitkaardiks nii loomaomanikule kui ka organisatsioonile. On tekkinud palju väikseid tõukeskseid koertefoorumeid, mis on enamasti seotud tõuühinguga. Samuti on varjupaigad ja aktiivsed loomadele suunatud heategevusega tegelevad organisatsioonid tänaseks väga korralikult veebis esindatud. Näitena võib tuua Tallinna ja Tartu loomade varjupaiga lehed - kui muutus varjupaiga teenust osutav organisatsioon, muutus ka koduleht. Võrreldes paljude väikelinnade varjupaikadega on Tartu ja Tallinna varjupaik Eesti ühed parimini toimivad ning seda peegeldab ka nende koduleht. Sama võib väita vabatahtlike loomadega seotud organisatsioonide kohta - tegusamal organisatsioonil on sisukam koduleht. Aretustegevust peetakse peaaegu võimatuks (või aretajat väheoluliseks), kui tal puudub korralik koduleht, mis tutvustab loomi, nende saavutusi, terviseuuringute tulemusi ja järglasi.

Küsimus on alati ja ennekõike inimestes, kes keskkonda peavad, samuti foorumi mugavuses, mis väljendub selles, et teatud asju on mõnes foorumis teha parem kui teises. Raske on öelda, miks kolisid kasutajad Bokseripesast Koertekotta: osaliselt on liikumised seotud inimeste omavaheliste probleemidega, osalt on põhjuseks foorumite järjepidevus, st teisel foorumil olid mitmed internetikatkestused, mistõttu kasutajad otsisid püsivama keskkonna. Lontu kadumise ning Pisi tõusu taga olid foorumi tehnilised probleemid. Kuna veebikeskkonna arendamine on protsess, siis võib kiirete muutuste ühe põhjusena eeldada juba nimetatud stimuleerivat suhtlemist. Kasutajad valivad selle järgi külastatava paiga, liidritest ja üldistest teemadest sõltub keskkonna sisu.

Kasutaja mugavuse kõrval on, nagu öeldud, oluline foorumi üldine suundumus. Praegu tõusuteel Kiisu.ee ja Kutsu.ee on meelelahutusliku suunitlusega. Sealse foorumi ülesehitus on noortele tuttavam ja mugavam, ka ei esinda see kuiva faktipõhist suhtumist, seal on rõhuasetus võimalusel levitada ja esitleda oma looma pilte, teha talle virtuaalselt pai, kommenteerida ja väljendada kui nunnu või armsa loomaga on tegemist. Seevastu Koertekoda on orienteerunud asjalikule ("täiskasvanulikule") informatsioonile ning suhtlusele; muidugi võib ka seal rääkida, kui nunnu on konkreetne loom, kuid tõsiseid teemasid on palju rohkem, need domineerivad. Seal ei ole mõeldudki sellele, et kasutajal oleks võimalikult mugav pilte lisada, samuti on piiratud isikliku galerii piltide hulk ja maht.

Samamoodi võib ütelda, et kuna Eestis ei ole tõukassid eriti levinud, ei ole kassid saanud nii korralikku ühtset foorumit kui koerad. On olemas mitmed kassifoorumid, kuid ei ole ühtset ja kompaktset keset nagu Koertekoda.ee. 
Eesti ajakirjanduses on viimasel paaril aastal ilmunud varasemast rohkem kirjutisi ja saateid loomadest. Ühelt poolt on selle taga kindlad ajakirjanikud, kes loomade vastu suuremat huvi tunnevad ja neid teemasid vahendavad, nii uudisväärtuse kui ka inimeste harimise mõttes ("Tartu varjupaiga hinnakiri muutub"). Teisalt on kahtlemata tegemist huviga nn kollaste uudiste vastu ("koertekari ründas", "surnuks piinatud"), kus uudislood kirjutatakse nende müüvuse tõttu, mitte selle tõttu, et teemaks on loomad. Seetõttu on ka loomadega seotute suhtumine ajakirjandusse kahetine - ühelt poolt kirutakse ajakirjanike objektiivsuse puudumist ja kallaklikkust, teisalt saab "ajakirjandusse minekut" kasutada mõjutusvahendina. Tuleb tunnistada, et kuigi objektiivset ja informatiivset ajakirjandust kiidetakse, leiab foorumites käsitlemist peamiselt tõrvatilk meepotis.

\section{Kellele veebilehed kuuluvad?}

Loomaveebi puhul on määrav legaalsus: ee-lõpulise veebiaadressi saab endale registreerida juriidiline isik ehk siis enamiku loomalehtede haldajateks on mingi MTÜ või firma. Huvitav on märkida, et ee-lõpulise aadressi omamist peetakse ka oluliseks - see justkui lisaks legitiimsust ja autoriteetsust. Palju lihtsam oleks osta endale mõne teise lõpuga domeen, kuid ükski oluline veebileht pole seda teed läinud, pigem vastupidi (Koertekoja foorum kolis .net aadressilt .ee aadressile).

Reklaamid jooksevad peaaegu kõigi keskkondade lehtede ülaääres (vt Kiisu.ee ja Koertekoda.ee), nii enesereklaam, heategevuslik kui ka makstud reklaam. Reklaamitulu, SMS-boonuste ostud ja kuulutuste tulu on veebis püsimiseks olulised. Firma eesmärk on ju teenida kasumit. Lemmik.ee üks sissetulekuid on just kuulutusetasud. Suuremate keskkondade kulud veebile on üle tuhande krooni kuus, samas kui väiksematel (nt Pisi.ee) on kulud üle kümme korda väiksemad. Väikeste kulude korral kipub MTÜ tegemine, MTÜ raamatupidamise korraldamine ja reklaami müük muutuma mõttetult suureks pingutuseks - lihtsam on halduskulud lehekülje omanikul ise tasuda ning MTÜ eesmärk on ka midagi muud kui raha teenida.

Huvi oma isiklikule loomale kodulehekülje valmistamiseks ei ole aga vastu eeldusi kasvanud. Põhjuseks võib olla mitme foorumi (nt Kutsu.ee) juurde loodud lihtne võimalus rajada kerge vaevaga analoogiline kodulehe-veebikeskkond, mis on kasutajale tasuta ning kergesti hallatav. Eelnev ei kehti aga nende kohta, kelle jaoks koer on midagi enamat perelemmikust. Kui tegemist on aretaja või treeneriga, jääb sellisest lehest väheks. 


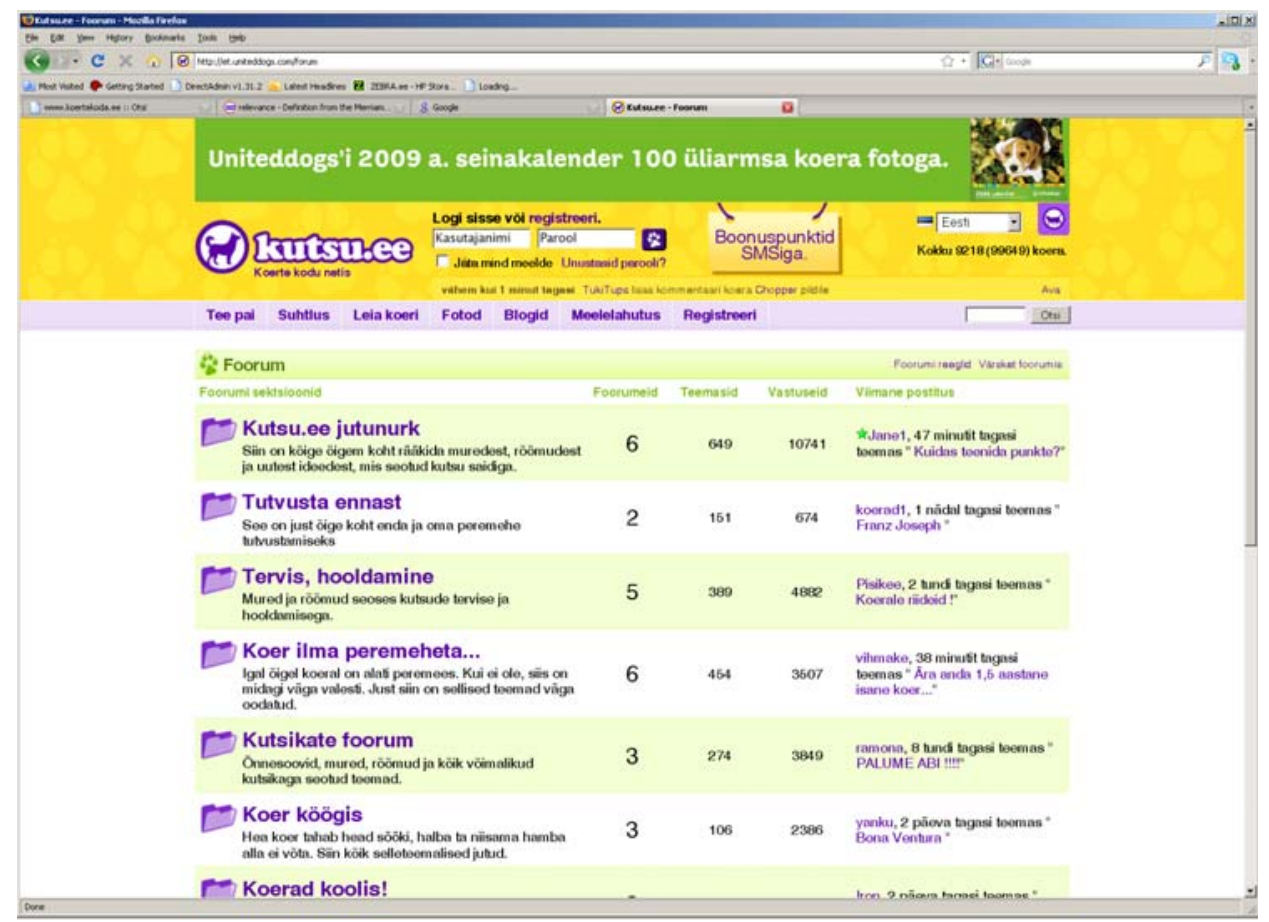

Joonis 1. Kutsu.ee foorumi avaleht.

Tõsistel tegijatel, aretajatel või koolitajatel on (oma loomadele) rajatud ulatusliku informatsiooniga veebilehed, kus on näidatud ära nende töösaavutused ja näitusevõidud - see on esinduslehekülg. Loomasoetamise rõõmus tehtud ilulehekülg kipub kiiremini ära vajuma kui esinduslikel kaalutlustel rajatud lehekülg, sest selle uuendamiseks nii palju aega ei võeta, ja päris kindlasti ei uuendata seda regulaarselt.

\section{Internet ei ole enam anonüümne}

Viimastel aastatel on peaaegu kadunud anonüümsed loomafoorumid, kus saab sõna võtta ilma kasutajaks registreerumata. Selle otsuse poole kallutas tegijaid kahtlemata spämmirobotite aktiivne tegevus foorumites, kuid mitte ainult. Anonüümse postitamise kadu mõjutas aga omakorda seda, millised on populaarseimad foorumid - kasutajanime loomine (meeles pidamine!) ja sellega sisse logimine on pingutus, mida iga tühise asja pärast teha ei viitsita. Pealegi piiras see anonüümset räuskamist ja poriloopimist.

Dave Briggs arutleb Dave Pressis anonüümsuse teemal, rõhutades: 
Minu jaoks on peamine küsimus usalduses. Veebipõhise sotsiaalse algatuse peamine mõte on pü̈̈da suurendada meediumisse kaasatud organisatsiooni ja süvendada suhtlejate vahelist usaldust. Kui organisatsioon on avatud ja läbipaistev ning pakub inimestele kohta oma vaadete väljendamiseks, siis kuidas saab tekkida usaldus, kui üks pool keeldub oma identiteeti avaldamast?”(Briggs 2008).

Näiteks Koertekoja foorumis olid pikad vaidlused selle üle, kas anonüümne postitamine on lubatud. Hoolimata mitmetest anonüümsetest sõnasõdadest oli registreeritud kasutajaskond pikka aega postitusõiguste piiramise vastu, rõhudes inimeste võimalusele saada kiiresti, kasutajaks registreerimata, vajalikku infot (vastuseid küsimustele).

Praegu on paljud alafoorumid nähtavad vaid sisselogitud kasutajale ja külalistel ei ole võimalik oma mõtteid ühtegi teemasse postitada. Sellise korralduse mõttekus ei ole enam kordagi päevakorrale tõusnud. Vastupidi: hiljuti lisandus võimalus märkida oma vanust ja arutleti, kas on vaja kasutajaid kodanikunimega identifitseerida.

Delfi Naistelehe lemmikloomafoorum on üks väheseid, kus on veel võimalik anonüümselt esineda. Erinevalt Delfi põhiosast, kus kommentaari juures on märge, millise nimega autor on varem samalt aadressilt postitanud (iseenesest samuti väga äsjane uuendus), on foorum täiesti anonüümne. Seetõttu suhtutakse sealsetesse teemaarendustesse ka teatava põlgusega - raske on teada, kas info allikas on tõsiseltvõetav. Samas eeldatavad sealse foorumi kasutajad, et inimene esineb ühe teema raames sama aliase all ja pidevat nimevahetust ei peeta heaks tooniks. Erinevates teemades korduvalt sõna võtjatelt eeldatakse sama aliase kasutamist ja peetakse halvaks tooniks, kui keegi võõras kasutab väljakujunenud aliast. Kuigi kiisumemm või $x x l$ tunduvad väga mittemidagiütlevad varjunimed ning tegemist pole registreeritud kasutajanimedega, loetakse neid nimesid konkreetsete inimeste omandiks.

Kohati on levinud ka kõigis külastatavates foorumites, ka anonüümsetes, sama aliase kasutamine. See aga tähendab, et kombineerides foorumite otsitavaid arhiive ning profiili ja enesetutvustuses avaldatud andmeid on inimesed kergesti identifitseeritavad. Äraandlikuks võib osutada see, et keegi tunneb su mõne ütluse põhjal ära, andmed võivad hargnema hakata ka meiliaadressist, veebilehest või kattuvusest Rate-kontoga. Väga kiiresti jäävad vahele valetajad, eriti noored, kes ei kujuta ette, kui hõlpsasti on nende andmed leitavad - kaasa arvatud see, mida nad mõne aasta eest kirjutanud on. Eesti väiksus saab väga selgeks - keegi kuskil foorumis ikka teab sind ja sinu tegusid. Väga raske on jääda täiesti tundmatuks. Tundmatuks jäämine aga polegi tihti enam eesmärk omaette, pigem tahetakse suurendada oma usaldusväärsust ja selleks on sama nime all esinemine on üks võimalus. Anonüümses foorumis 
on üheks vahendiks ka postituse juurde oma meiliaadressi lisamine, kusjuures kasutatakse meiliaadressi, mille kaudu postitaja isik on kergesti tuvastatav.

\section{Netiketita ei saa kuidagi}

Enamikul foorumitest on üpris rangelt paika pandud reeglid, mida tohib ja mida ei tohi teha, kuidas väljenduda. Reeglistik on kõigis foorumites üsna sarnane, kehtib nn elementaarne netikett. 2004. aastal olid paljud foorumid mitte üksnes anonüümsed, vaid ka reeglistik oli labiilsem. Praeguseks on moderaatorid palju rangemad. Reeglite karmus oleneb foorumi administratsiooni meelsusest ja senisest kogemusest kasutajatega. Pole ju mõtet keelata võoraste piltide kasutamist, kui keegi seda nagunii ei tee. Või laimuga esinemist, kui keegi ei laima. Kõige karmim karistus on kasutajale juurdepääsu keelamine alatiseks. Leebemate vormide seas on avalikud noomitused ja kasutaja sildistamine ("roppröökur").

\section{Noored ja vanad, mehed ja naised}

Lemmikloomad ei ole teema, mis oleks aktuaalne vaid mingile vanuserühmale või ühele soole. Lemmiklooma teema ja vastavad foorumid on ühed nendest, kus ei teki vanuselist vanade ja noorte eristumist, sest kogu aeg lisandub uusi kasutajaid. See tähendab, et lisandub pidevalt noori, kuid kogu aeg tuleb juurde ka vanemaid inimesi, kes tahavad rääkida lemmikloomadest. Lisaks saavad noorena liitunud kasutajad vanemaks. Teisalt kaob kogu aeg neid, kellel enam ei ole oma looma või kes tüdineb vestlemisest ja lahkub. Teema on aga universaalne ja selle juures on hulgaliselt korduma kippuvaid küsimusi, alates ettevaatlikust pinnasondeerimisest, á la tahan võtta endale kassi või koera kuni selleni, et vajan abi mingi kindla probleemiga.

Stephen Kellert ja Joyce Berry on iseloomustanud naiste ja meeste erinevat käitumist ja erinevaid ootusi seoses loomadega ning võtnud selle kokku üldistusega, et meeste ja naiste emotsionaalne ja kognitiivne suhe loomadesse on erinev. Meestel domineerib utilitaarne suhtumine, neil on keskne praktiline ja materiaalne väärtus ning teisalt on täheldatav looma suhtes domineeriv käitumine ehk siis kontroll looma üle, esiplaanil on sport ja sportlikkus.

Naisi on nad iseloomustanud kui antropomorfiseeriva käitumise ja suhtlemistüübi esindajaid, kes on hõivatud loomakaitse ja -varjupaikade tööga. Teisalt on naistele iseloomulik teatav moraliseeriv (ekspluateerimise vastased) ja 
humanistlik lähenemine (sentimentaalsed ja nostalgilised suhted) loomadele (Kellert \& Berry 1987, vt ka Peek \& Dunham \& Dietz 1997).

Sama kehtib üldiselt ka Eesti loomafoorumites. Tahtmata siinkohal süüvida inimeste ja loomade suhetesse on siiski statistiliselt ilmne, et mehed on loomafoorumites selges vähemuses. Koolitusseminaridel ja koeraspordis on enamik osalejaid naised, isegi prestiižsed suured "meeste" koerad nagu dobermann ja bokser on palju rohkem naiste teema.

Mehi on rohkem tegelemas akvaristika ja roomajate teemaringiga. Ehk on asi erinevates vajadustes, mida selliste loomadega tegelemine rahuldab? Mao, sisaliku või ämblikuga suheldakse teisel tasemel kui kassi või koeraga. Sa võid nendega rääkida ja nad võivad õppida sind tundma, ent nad ei otsi ise kontakti. Samas vajavad nad pidevat ja täpset hoolitsust. Õige temperatuur, kindel valgustus ja muud tingimused peavad olema nende loomade puhul stabiilsed. Kilpkonn, kelle sa lihtsalt radiaatori alla unustad, sureb kiiresti. Koerad ja kassid suudavad ennast arusaadavaks teha ja väljendada oma vajadusi, nad on ka vastupidavamad kui eksootilised loomad, kes on pärit hoopis teistest kliimaoludest. Kahepaiksete ja roomajate vajadusi ja soove ei aima omanik kuigi kergesti, nad ei ole pehmed ega nunnud. Neil on oma haigused, mida on raske diagnoosida, vähe on arste, kes haiguse ära tunnevad. Ravi on see tõttu raske ja ravimeid pole saada. Tõenäosus lemmiklooma kaotada on palju suurem, samal ajal kui kasside-koerte haigused on märgatavamad ega ole nii ohtlikud. Kui koer korjab üles rebase kärntõve, siis on lugu karm. Aga see on vähemasti silmaga nähtav. Kui su kilpkonnal on ussid või leeguanil nahaparasiidid, ei pruugi sa sellest arugi saada.

\section{Uus keskkond - looma-rate}

Tuntud loomade ja inimeste suhete uurija James Serpell toob esile tänapäevase ühiskonna tunnusena teatava intiimse käitumise ja nostalgia tõrjutuse, mis on arvatavasti suurendanud nende keskkondade populaarsust, kus on võimalik väljendada oma tundeid:

Arvestades, et me elame ühiskonnas, kus vähemalt avalik täiskasvanute vaheline fü̈̈siline lähikontakt on tugevalt taunitud, pakuvad lemmikloomad meile hinnalise ja ühiskondlikult aktsepteeritud võimaluse käituda intiimselt (Serpell 1996: 132).

Väga kiiresti on kasutajaskonna seas populaarsust kogunud Kiisu.ee ja Kutsu.ee. Meelelahutus, teabe jagamine, emotsionaalsete seikade jagamine on nende portaalide märksõnad. Ülesehituselt on nad sarnaned noorte seas 


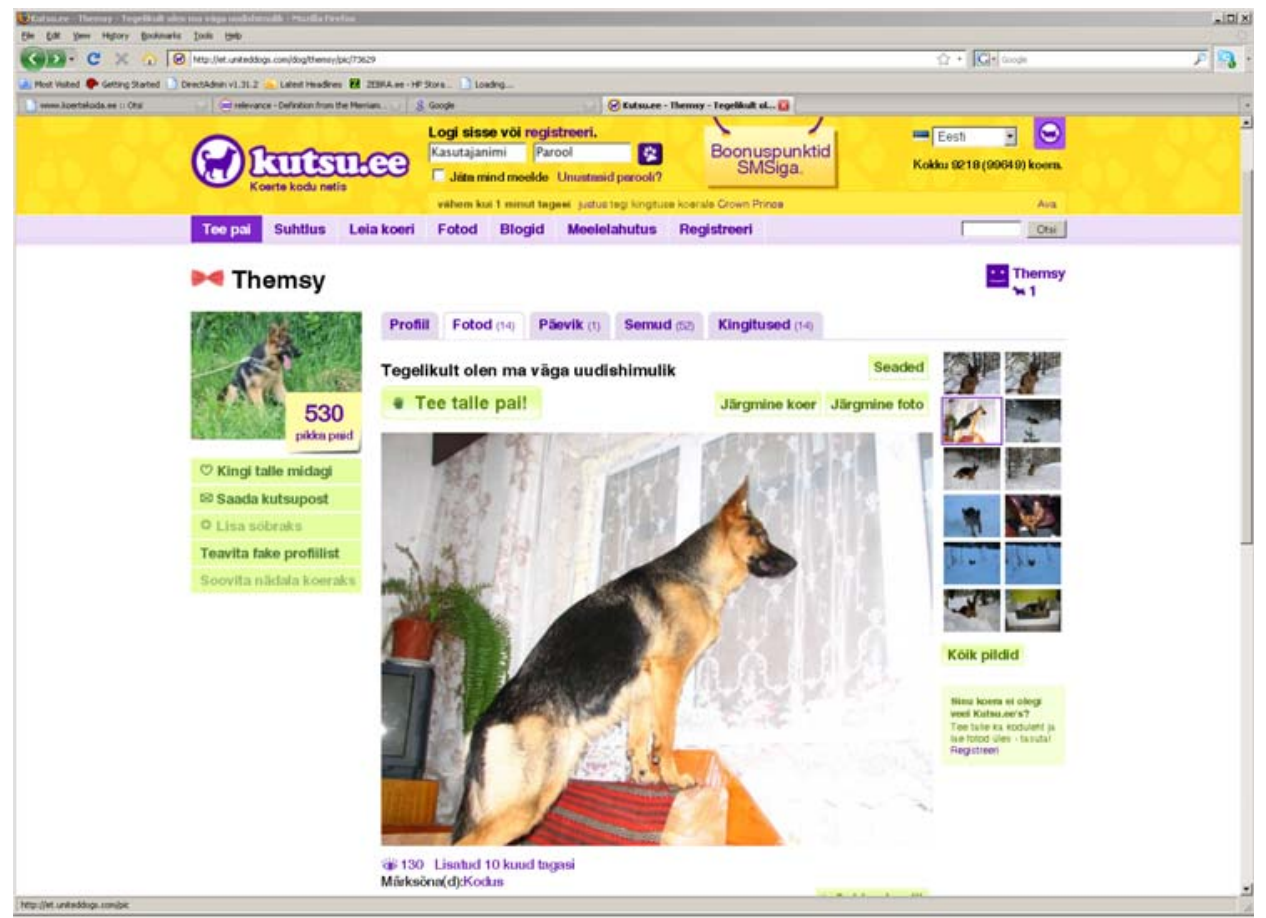

Joonis 2. Saksa lambakoer Themsy kodulehekülg kinnitab väidet, et meelelahutusliku veebikodu eest hoolitsemine jääb tihti ajapuudusel unarusse - aasta jooksul on kogunenud paisid ja kingitusi, aga pilte ja teavet pole lisandunud.

populaarsele Rate.ee keskkonnale. Omanik saab üles panna looma pildid, samamoodi saab hinnata pilte, anda kontaktid. Olemas on tähtis teema nagu nädala kass ehk siis populaarseim loom. Esitletud loomale saab saata kingitusi, teha virtuaalselt pai ja keskkonnal on oma kõige tavalisema ülesehitusega foorum. Looma-rate teemad on kerge lobisemine oma looma teemal, info saamine, tervisekäitumine, loomale kodu otsimine, kuulutused ja järeltulijad. Põhiline tegevus koondub aga ikkagi piltide ja nende hindamise ümber: saad tegevusega punkte koguda, aga võib saata ka sms-sõnumeid või raha eest osta endale punkte nagu inimeste Rate.ee-s. Kassidele nagu inimestelegi on võimalik koostada profiil peamiste isikuandmetega - kuidas ennast iseloomustad ja kes sa oled, leheküljele lisatud digitaalne kaart näitab elukoha.

Kõige lihtsam on iseloomustada sellise keskkonna erijooni konkreetse looma näitel. Valisin populaarsete kasside seast valge pikakarvalise kassi Jesse. Jessele on tehtud 86 pikka virtuaalset pai, saadetud virtuaalseid kingitusi ja mitmed kassid on märkinud ta oma sõbraks. Jesse on noor kass, mis on ilmselt üks populaarsuse põhjuseid, sest kassipojad ja noored loomad on üldjuhul 
inimeste arvates armsad ja kenad. Jesse omanikul on ainult üks kass, kellele on veebileht tehtud.

Isikuandmete juurest saame teada näiteks kassi hüüdnimed, mida võib lisaks pärisnimele olla mitu. Jessel on neli hüüdnime: Jessu, Juunior, Kreemirull, Pätt. Nimede vahendusel saame natuke teada looma iseloomu kohta.

Looma-rates võib saab ka blogi oma looma kohta. See võimalus on kõigil kasutajatel, kuid enamasti ei ole see pikaajaline harrastus, sest mõne aja pärast huvi vaibub.

Üldiselt on vaadatuimate lehekülgede ja teemade valik lai. Looma-rate vaadatuimate lehekülgede hulgas on näiteks armastatud surnud kassile pühendatud lehekülg, kus fotole on lisatud omaniku kurb järelehüüe ja foorumikülastajate kaastundeavaldused. Populaarsemate hulka kuuluvad rubriik "Kadunud ja leitud kassid" ning kodu otsivate pesakondade kuulutused.

On kirjutisi, mis kutsuvad suhtlema ja õhutavad dialoogile. Näiteks on üks perenaine oma kassi pildile lisanud mina-vormis jutukese arsti juures käimisest, mis on äratanud lugejates huvi kommenteerida: kullakesele soovitakse paranemist; kass vastab: Tänan, mul on juba parem.

\section{Tasulised kuulutused}

Loomaomanike arv läänelikes ühiskondades on kõrge, vaatamata potentsiaalsetele ja reaalsetele kulutustele lemmiklooma pidamisel (vt Bonas \& McNicholas \& Collis 2000: 209 jj). Tänaseks on lisandunud näiteks meediakulutused. Kuulutustelehed on läinud kallimaks, on muudetud kujundust. Kui mõne loomaportaali kuulutuste nurka ei pruugita lugeda, siis suured kuulutustelehd nagu Soov ja Kuldne börs on juba üle aasta avaldanud loomakuulutusi tasu eest. Kuulutuste arv on suurenenud ning eristunud on tõuta ja tõu- koertekasside kuulutused. Loomade fotode ja kuulutuste paberlehes avaldamine on alati tasuline olnud, kuid enam ei saa ka veebis tõuloomade kohta tasuta infot avaldada.

Tasulistes kuulutustes reklaamivad ennast nii tõuloomadele, segaverelistele kui teise ringi loomadele kodude otsijad.

\section{Pildid kui keskne tõmbenumber}

Visuaalsusest kui veebi olulisest komponendist, ja sellest, et disain ei ole üksnes dekoratsioon, vaid dikteerib interaktsiooni või koguni kasutajahuvi, on arvukalt kirjutatud. Loomafoorumites esitletud pildid on enamasti omatehtud ja sageli üsna tehnilised. Enamik pilte ütlevad midagi ainult omanikule. Nii 
nagu perekonnaalbumis jaksab sugulaste pilte vaadata ikkagi eeskätt isik, kes neid inimesi tunneb, ei ole suvalised kassi- ja koerapildid vaatajale ilu- ega naljapildid ega mõeldud fotograafia-foorumile. Oma looma ilu näed eelkõige ikka ise.

Loomalehekülgede vaatajate arv on suurem tõukoera või muu tõulooma puhul, sest tal on palju sugulasi, ja lisaks on tõu vastu huvi tundev vaatajaskond hoopis laiem kui tuttavalt või turuväravast soetatud sugupuuta loomal. Veebilehekülgi ja huvilisi jagub aga ka rajatud segaverelistele loomadele omaniku tutvuskond ehk "koera sõbrad" ning lihtsalt ilusate loomapiltide otsijad.

\section{Kokkuvõtteks}

Üldise internetiseerituse taustal on tõusnud ja laienenud loomateema esindatus veebis ehk siis - kui sa oled tõsine tegija, siis sa pead olema ka internetis, sest nagu igal muul elualal, kehtib ka Eesti lemmikloomanduses reegel - kui sind ei ole veebis, siis sind ei ole olemas.

Meelelahutuslike uusfoorumite puhul on primaarne foto või fotode veebis eksponeerimine, foorum on selle juures hobi, meelelahutuse ja täiendava komponendi ülesannetes. Problemaatilisi teemasid ei taheta lahata. Eriti selgelt on tuntav vastandumine koeri puudutavates teemades Kutsu.ee (meelelahutuslik; tulu teeniv; modereeritav) vs Koertekoda.ee (probleemide käsitlus; mittetulunduslik; modereeritav) vs Delfi loomafoorum ("peldikusein"; tulu teeniv; moderaatorita). Sama võib märkida pisiloomade foorumi Pisi.ee juures, mis kuulub MTÜle, millel on askeetlik kujundus ning suunatus sisule. Disain on kasutajale küll oluline, kuid keskkonna valikul mitte peamine komponent.

Muutused veebis peegeldavad muutusi väärtushinnangutes. Hulkuvad koerad on enamvähem kadunud, kasse veel leidub. Koerte hulkuma laskmist taunitakse täielikult, kasside osas on suhtumine aastatega aina teravamaks läinud. Paranenud elukvaliteet on kaasa toonud eluea kasvu ja põhjustanud terava ülepopulatsiooni probleemi, kuna kasside-koerte tänaval elamist ei peeta enam aktsepteeritavaks. 2004. aastal ei olnud kassidel abiorganisatsioone, kes korjaksid neid tänavatelt ja tegeleksid nendega. Praeguseks on tollal omal käel tegutsenud vabatahtlikud liitunud abiorganisatsioonidesse (Kassiabi, Kasside turvakodu, jt), mille kaudu leiavad igal aastal kodu sajad kassid. Neil organisatsioonidel on oma kodulehekülg, nad avaldavad aktiivselt kuultusi loomafoorumites ja nad on ühiskonnas tuntud.

Anonüümsuse kadu internetis on nähtav ka loomafoorumites - anonüümsust kui sellist ei väärtustata, julgetakse esineda oma nime all ja eeldatakse 
seda ka vestluspartnerilt. Anonüümseid allikaid ei väärtustata, nende informatsiooni tõepärasus seatakse kahtluse alla.

\section{Kommentaar}

${ }^{1}$ Artikkel on seotud ETF grandiga nr 6824.

\section{Kirjandus}

Beck, Alan \& Katcher, Aaron (1996). Pets can be self. Between Pets and People: The Importance of Animal Companionship. West Lafayette, lk 63-77.

Bonas, Sheila \& McNicholas, June \& Collis, Glyn M. 2000. Pets in the network of family relationships: an empirical study. Podberscek, Anthony L. \& Paul, Elisabeth S. \& Serpell, James A. (toim). Companion Animals and Us. Exploring the Relationships between People and Pets. Cambridge: University of Cambridge Press, lk 209-233.

Briggs, Dave 2008. Anonymous contributions. Dave Press (http://davepress.net/2008/ 02/03/anonymous-contributions/ - 4. detsember 2008).

Chayko, Mary 2002. Connecting: How we form social bonds and communities in the Internet age. New York: State Univeristy of New York Press.

Fialkova, Larisa \& Jelenevskaja, Maria 2001. Vaimud kübermaailmas. Interneti folkloorisaitide analüüs. Artikkel VTK raamatust (http://www.folklore.ee/seminar/ fialkova3a.html - 4. detsember 2008).

Kellert, Stephen R., \& Berry, Joyce K. 1987. Attitudes, knowledge, and behaviors toward wildlife as affected by gender. Wildlife-Society Bulletin, 15, lk 363-371.

Kiilmaa, Ethel 2001. Lemmikloomad on moes. Äripäev. 15. 06. 2001 (http://ap3.ee/ Default2.aspx?PaperArticle=1\&code=1948/rpp_elustiil_194801 - 4. detsember 2008).

Peek, Charles W. \& Dunham, Charlotte Chorn \& Dietz, Bernadette E. 1997. Gender, relational role orientation, and affinity for animal rights. Sex Roles: A Journal of Research (http://findarticles.com/p/articles/mi_m2294/is_n11-12_v37/ai_20391900/ pg_1?tag=artBody;col1\# - 4. detsember 2008).

Serpell, James 1996. In the companion animals. A study of human-animal relationships. Pennsylvania: Cambridge University Press.

Vesik, Liisa 2004. Lemmikloomad Eesti veebis. Väike ebatäielik ülevaade: foorumid, portaalid, loomasõbrad, varjupaigad, kuulutused, kodulehed. Renata Sõukand (koost) Interdistsiplinaarne seminar "Inimesed ja lemmikloomad", teesid. Tartu: Eesti Kirjandusmuuseumi folkloristika osakond \& MTÜ Eesti Folkloori Instituut, lk 11 (http:// www.folklore.ee/pubte/loomad/tees.pdf - 4. detsember 2008). 


\section{Veebilehed}

Akvaristika http://foorum.akvarist.ee/welcome.php

Bokseripesa http://bokseripesa.koer.info/forum/

Delfi Naistelehe lemmikloomafoorum http://woman.delfi.ee/foorum/list.php?f=24

Eesti Loomakaitse Selts http://www.loomakaitse.ee/et/

Kassiabi http://www.kassiabi.ee/

Kasside turvakodu http://www.kassideturvakodu.ee/avaleht.php

Kiisu.ee http://www.kiisu.ee

Koertekoda http://www.koertekoda.ee/forum/

Kuldne Börshttp://www.kuldnebors.ee/kuulutused/Lemmikloomad/kuulutused.mec?pob_cat_id= 11166\&pob_action=show_cats

Kutsu.ee http://www.kutsu.ee

Lemmik http://www.lemmik.ee

Lontu http://www.lontu.ee [4. detsember 2008 - võlgnevuse tõttu suletud]

Pisi http://www.pisi.ee

Roomajad ja ämblikulaadsed http://www.reptile.ee/

Soov http://www.soov.ee/tulemused.seam?pageNumber $=1 \&$ catId=10812\&cid=459211

Tallinna kodutute loomade hoiupaik http://www.loomadehoiupaik.ee/

Tartu kodutute loomade varjupaik http://www.loomadevarjupaik.ee/

Verekoer http://www.koer.ee

\section{Summary}

\section{Estonian Pets Online - The Past Five Years}

\section{Liisa Vesik}

Key words: anonymity, pet boards, pet portal, pets, virtual communities

The article outlines the changes that Estonian public pet web pages and pet forums have undergone in 2004-2008. Evolution has caused changes in both the technological solutions of these portals as well as in the contents, reflecting a shift in people's attitudes and values. Web sites have an important representative role, and the use of ee-domains adds authority on the Estonian web. Recently, there has been a significant shift away from anonymity on message boards in terms of registered and identifyable users as well as a more efficient control of adherence to netiquette. More classifieds are being published online, and not only on free sites. The primary aim of pet forums and portals is dissemination of information, but the sites intended mostly for entertainment purposes are on the rise. Users choose which web environments to visit not only based on their design and ease of use, but based on a combination of these qualities, and also depending on the needs of individual users. 